\title{
CCDC6/RET Fusion Gene
}

National Cancer Institute

\section{Source}

National Cancer Institute. CCDC6/RET Fusion Gene. NCI Thesaurus. Code C18573.

A fusion gene that results from a chromosomal inversion inv(10)(q11q21) which fuses the 5' part of the CCDC6 gene with the 3' part of the RET gene. This gene fusion is associated with papillary thyroid carcinoma. 